\title{
Phenotypic Traits, Grain Yield and Yield Components of Maize Cultivars Under Combinations of Management Practices in Semi-arid Conditions of Iran
}

\author{
Maryam Rahimi Jahangirlou ${ }^{1,3} \cdot$ Gholam Abbas Akbari $^{1}$ (1) Iraj Alahdadi ${ }^{1} \cdot$ Saeid Soufizadeh $^{2} \cdot$ Uttam Kumar $^{3}$. \\ David Parsons ${ }^{3}$
}

Received: 6 January 2021 / Accepted: 26 July 2021 / Published online: 3 August 2021

(c) The Author(s) 2021

\begin{abstract}
In semi-arid regions, selecting cultivars and planning management practices are critical issues for improving yields and reducing risks of maize cultivation in the short summer cropping season. This study aimed to assess the responses of grain yield (GY) and important phenotypic characteristics of maize cultivars from different maturity groups under various irrigation regimes, planting dates, and nitrogen rates, in a 2-year experiment. According to the clusters identified in the loading plot, stover yield, radiation use efficiency (RUE), height, leaf greenness index, stem weight, and ear size during flowering (VT/ R1) were strongly correlated with GY, yield components and harvest index. Based on analysis of variance, more irrigation or $\mathrm{N}$, or their interaction often increased GY, rows ear ${ }^{-1}$, grains row $^{-1}$ and hundred-grain weight. Late planting decreased GY of KSC704 (late maturity cultivar). KSC260 (early maturity cultivar) had greater flexibility in planting time, required less days for maturity, and had less water consumption. The findings highlight the physiological basis of the relationship between the different phenotypic characteristics and how they affect GY and its components. They were in line with the established theories that higher RUE, biomass and sink activity (e.g. grain weight and numbers, and larger ear size) are associated with better genetic gains to produce high GY. Although the results were not consistent between years, findings suggested the good performance of recently released early maturity cultivars for use during the summer growing season.
\end{abstract}

Keywords Early maturity cultivars $\cdot$ Irrigation $\cdot$ Nitrogen $\cdot$ Planting date $\cdot$ RUE $\cdot$ Sink activity

\section{Introduction}

Semi-arid areas are characterized by low precipitation and high spatial and temporal variability leading to negative impacts of severe temperature and drought on crop production (Murungweni et al., 2016). Iran is a country in the midlatitude belt of the arid and semi-arid zones (Modarres et al., 2007). Maize in Iran is one of the most important crops

Gholam Abbas Akbari

ghakbari@ut.ac.ir

1 Department of Agronomy and Plant Breeding Sciences, College of Aburaihan, University of Tehran, Pakdasht, Iran

2 Department of Agroecology, Environmental Sciences Research Institute, Shahid Beheshti University, G. C., Tehran, Iran

3 Department of Agricultural Research for Northern Sweden, Swedish University of Agricultural Sciences, 90183 Umeå, Sweden that is widely cultivated as a second and summer crop after the winter cereals like wheat and barley (Rafiee \& Kalhor, 2016). During the summer season, stress impacts on crop performance can be more common and persistent. Strong effects of genotype-by-environment interaction, extreme temperatures, and the short cropping time are among the most important factors that impair the development and functioning of morpho-physiological traits and grain yield of maize crops during summer (Adnan et al., 2020; Moradi et al., 2013). In addition, challenges of inadequate water and low fertilizer use efficiency because of volatilization or leaching are other important reasons for maize yield loss in these areas (Moradi et al., 2013, 2014; Nasielski et al., 2019).

There are several strategies recommended and adopted by breeders and farmers to reduce the yield gap in the arid environmental zone. Optimal combinations of sowing window and cultivar are among the most important strategies for minimizing the impact of drought and heat during 
summer on anthesis and autumn cold on grain filling in that environment (Chen et al., 2020; Padovan et al., 2020).

For summer cropping in semi-arid parts of Iran, while early planting is better for yield maximization by taking advantage of spring rainfalls for better germination and crop establishment, however, farmers are advised to postpone cultivation to prevent synchronizing of the maize reproductive stage with extreme temperatures (Moradi et al., 2014). In addition, farmers are recommended to use early maturity maize cultivars (Moradi et al., 2013, 2014), so that they can reach maturity before the onset of autumn cold. Additionally, early maturity cultivars consume less water, due to a shorter maturation cycle (Jahangirlou, 2015). However, early maturing cultivars are not well received by farmers due to their high yield loss under water and $\mathrm{N}$ stresses, compared with late maturing ones (Jahangirlou, 2015).

In recent years, grain yield and agronomic aspects of new maize cultivars have been improved due to breeding efforts. Screening the phenotypic characteristics, grain yield and yield components of the best performing cultivars under multi-environment trials and stress conditions is an important strategy for investigating their behavior to genetic by environment interactions.

Grain yield, as a complex variable, can reflect the interaction of the environment and management with the growth and development processes that occur throughout the crop's maturation cycle (Studnicki et al., 2016). In addition, yield component traits adjust their expressions to determine grain yield under different environmental and agronomic conditions (Kumar et al., 2016, 2017). Since the reduction in grain yield and yield components of cultivars under stress conditions is often correlated with changes of some phenotypic expressions (Kumar et al., 2017), the evaluation of phenotypic traits are more important. As an example, variation in intercepted photosynthetically active radiation (IPAR) due to changes in location, year and planting date is the main cause of variation in the phenology, kernel set and harvest index (HI) of maize crop (Tsimba et al., 2013). Grain yield reductions due to drought stress at different growth stages are well documented, and the causes are associated with reduced tissue expansion and biomass, cell turgor, plant height elongation, ear elongation, number of fertilized ovaries, and reduced kernel number (Ruiz et al., 2019). The reduction of grain yield can also be associated with the reduction in IPAR due to changed phenology, LAI, and stress intensity (Sarlikioti et al., 2011; Shi et al., 2015; Villegas et al., 2016). In contrast, sufficient water and nitrogen $(\mathrm{N})$ rates increase dry matter accumulation in maize grain due to enhancing leaf area and chlorophyll content, absorption of solar radiation, and biomass partitioning to individual organs, especially stems as reservoirs to remobilize assimilates to grain (Boomsma et al., 2010; Zhou et al., 2018).
Breeders have developed high yielding early maturity maize cultivars in the recent years, but understanding their responses to diverse systems of cultivation is limited. Identifying correlated phenotypic characteristics with grain yield and their response to challenging agronomic factors or interactions is key for developing strategies required to enhance and stabilize grain yields. Therefore, this study aimed to (i) evaluate the responses of locally popular maize cultivars from different maturity classes to combinations of planting times, irrigation, and $\mathrm{N}$ regimes to gain a quantitative understanding of yield formation, and (ii) identify important phenotypic characteristics affecting grain yield and its components. A motivation of the study was to provide useful knowledge, more efficiently use money and time defining and conducting future research, and develop guidelines to enhance maize grain yield and reduce production risks in Iran.

\section{Material and Methods}

\section{Experiment Site}

The field experiments were performed in 2018 and 2019 in Pakdasht city $\left(35.4669^{\circ} \mathrm{N}, 51.6861^{\circ} \mathrm{E}\right)$, Tehran province, Iran. The geographical location of Pakdasht city in Iran is shown in Fig. 1. According to the de Martonne index climate classification, this region has a semi-arid climate with relatively cold winters and hot dry summers (Emadodin et al., 2019). Irrigated summer maize in this region is often cultivated after winter cereals like wheat and barley. Summaries of minimum and maximum average temperatures and precipitation during the summer maize growing season for the two experimental years are presented in Fig. 2. The highest average temperature occurred in July and the total growing season precipitation was less than $1.0 \mathrm{~mm}$ in each year.

Soil sampling was done before the first cultivation year. The samples were air dried, passed through a 2-mm sieve, and tested for organic carbon using the Walkley-Black method (Walkley \& Black, 1934), total N using the Kjeldahl method (Bremner, 1960), available phosphorus (P) by the Olsen procedure (Olsen et al., 1954) and available Potassium (K) using a flame photometer (Mehlich, 1953). Based on particle size analysis, the texture was characterized as clay-loam. The initial physico-chemical characteristics in the 0-30 cm soil layer were as follows: organic carbon, $1.09 \%$; total $\mathrm{N}, 0.12 \%$;, $90.17 \mathrm{mg} \mathrm{kg}^{-1} ; \mathrm{K}, 453 \mathrm{mg} \mathrm{kg}^{-1}$.

\section{Experimental Design}

In mid-June 2018 experimental strips and plots were designated at a farm where no crops had been cultivated for the previous 3 years. The field was divided into two strips 
Fig. 1 The geographical location of Pakdasht city $\left(35.4669^{\circ}\right.$ $\left.\mathrm{N}, 51.6861^{\circ} \mathrm{E}\right)$, Tehran province, Iran

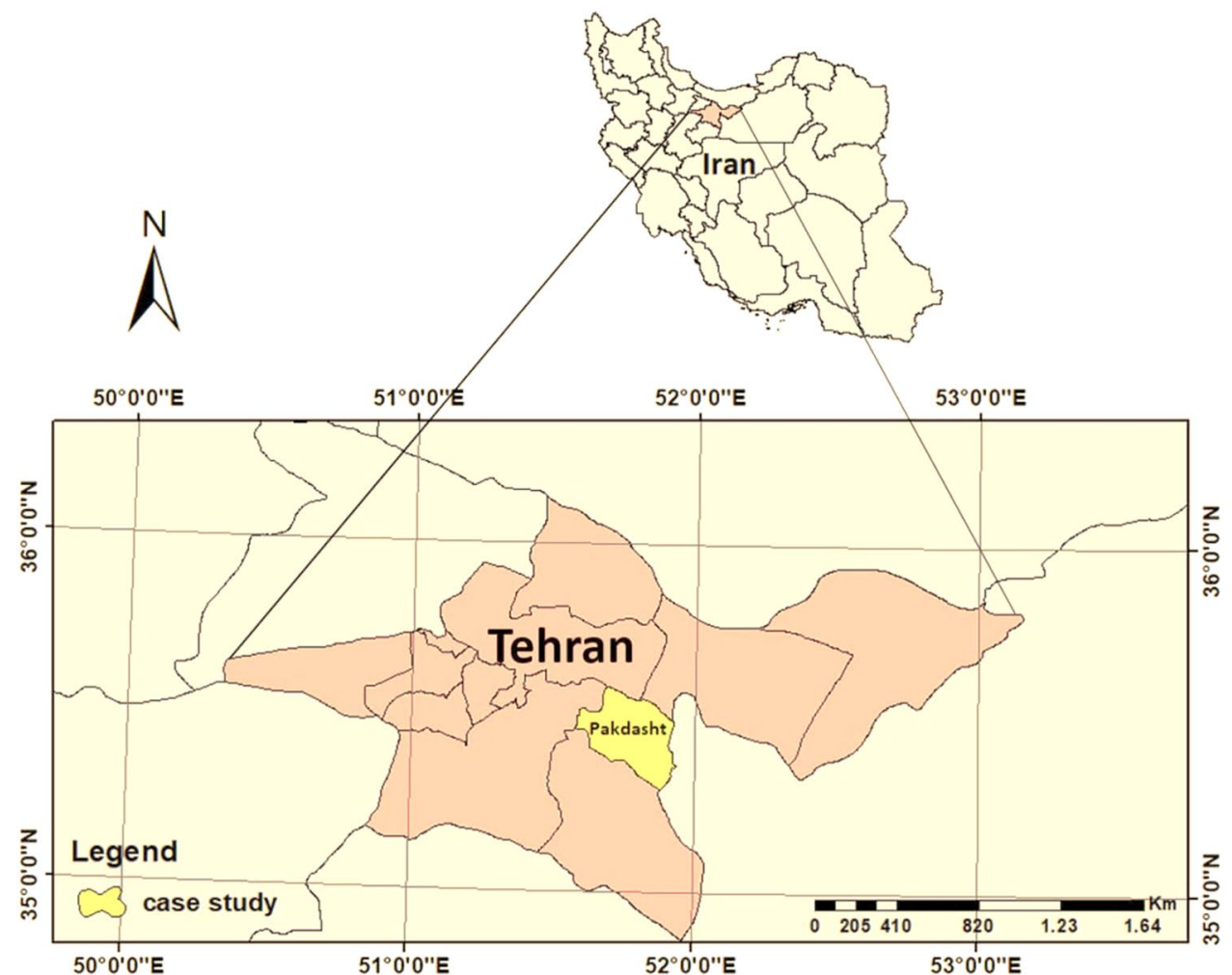

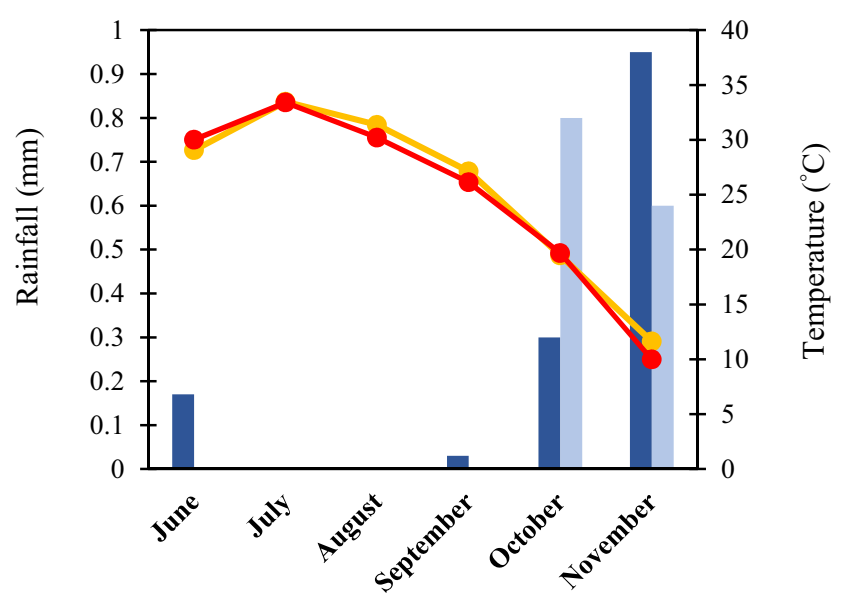

Months

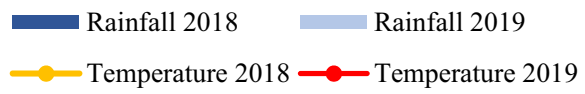

Fig. 2 Average air temperatures and monthly total precipitation during the summer maize growing season from June through November of 2018 and 2019, in Pakdasht city, Iran

(24-m length) to apply different irrigation timings (12-day and 6-day intervals). Two planting dates (20 June and 21 July) were randomized within the irrigation treatments. Two ditches crossed the strips, partitioning each of them into three plots. Thus, the experiment comprised twelve main plots. The four combinations of cultivars (KSC704 and KSC260) and $\mathrm{N}$ rates ( 0 and $184 \mathrm{~kg} \mathrm{ha}^{-1}$ ) were randomized to subplots within each plot. Thus, a total of 12 main plots containing a total of 48 sub-plots were obtained from three replications in each cultivation year. Individual sub-plots were $6 \mathrm{~m}$ in length and consisted of 6 rows sown at a density of six and eight plants per square meter for KSC704 and KSC260, respectively. Treatments were applied to the same plots in each year.

KSC704 is a locally popular high-yield late maturity hybrid which has been cultivated in Iran since 1980 and accounts for $80 \%$ of the maize growing areas of Iran (Estakhr et al., 2015). KSC260, an early maturity maize cultivar, was introduced in 2008, and has shown good performance in various experiments comparing new early-maturing cultivars (Jahangirlou, 2015). Harvesting date, maturity period and the total growing degree days (GDDs) of cultivars in present study are shown in Table 2. GDD was calculated using GDD calculator program (Soufizadeh, 2012). For this study, $10{ }^{\circ} \mathrm{C}$ as the base temperature and 34 and $40{ }^{\circ} \mathrm{C}$ as the optimum and maximum temperature thresholds, respectively, were adapted from Cutforth and Shaykewich, (1990). The two planting dates were chosen to create different temperature conditions during grain filling. The variability of daily average temperature during the reproductive period (listed in Table 1) for both planting dates in 2018 and 2019 is shown in Fig. 3. There were clear differences between the recorded temperatures for the planting dates in each year, 
Table 1 Planting and harvesting dates, growing degree days (GDDs) to harvest, vegetative (VE to VT), reproductive (VT to R6) and physiological maturity (VE to R6) periods of cultivars in 2018 and 2019

\begin{tabular}{llllllll}
\hline Year & Maize hybrids & Planting date & Harvesting date & GDD $\left({ }^{\circ} \mathrm{C}\right)$ & $\begin{array}{l}\text { Vegetative } \\
\text { period (days) }\end{array}$ & $\begin{array}{l}\text { Reproductive } \\
\text { period (days) }\end{array}$ & Maturity period (days) \\
\hline 2018 & KSC704 & 20 June & 7 November & 2424 & $73.4 \pm 0.8$ & $65.8 \pm 0.1$ & $138.5 \pm 1.0$ \\
& & 21 July & 26 November & 1839 & $65.2 \pm 2.5$ & $70.7 \pm 1.1$ & $136.0 \pm 1.3$ \\
& \multirow{2}{*}{ KSC260 } & 20 June & 18 October & 2311 & $62.6 \pm 1.3$ & $55.8 \pm 0.3$ & $118.5 \pm 1.0$ \\
& & 21 July & 11 November & 1796 & $55.6 \pm 4.0$ & $59.8 \pm 2.3$ & $115.5 \pm 1.6$ \\
2019 & KSC704 & 20 June & 2 November & 2370 & $69.0 \pm 2.0$ & $64.8 \pm 1.3$ & $133.8 \pm 1.0$ \\
& & 21 July & 28 November & 1855 & $62.7 \pm 1.5$ & $65.7 \pm 15$ & $128.6 \pm 0.9$ \\
& \multirow{2}{*}{ KSC260 } & 20 June & 12 October & 2220 & $66.5 \pm 4.0$ & $52.0 \pm 2.3$ & $118.5 \pm 1.7$ \\
& & 21 July & 14 November & 1704 & $59.0 \pm 2.0$ & $62.7 \pm 1.5$ & $114.5 \pm 1.2$ \\
\hline
\end{tabular}

Temperature thresholds to calculate GDDs were $10^{\circ} \mathrm{C}$ (base temperature), $34{ }^{\circ} \mathrm{C}$ (optimum) and $40{ }^{\circ} \mathrm{C}$ (maximum)

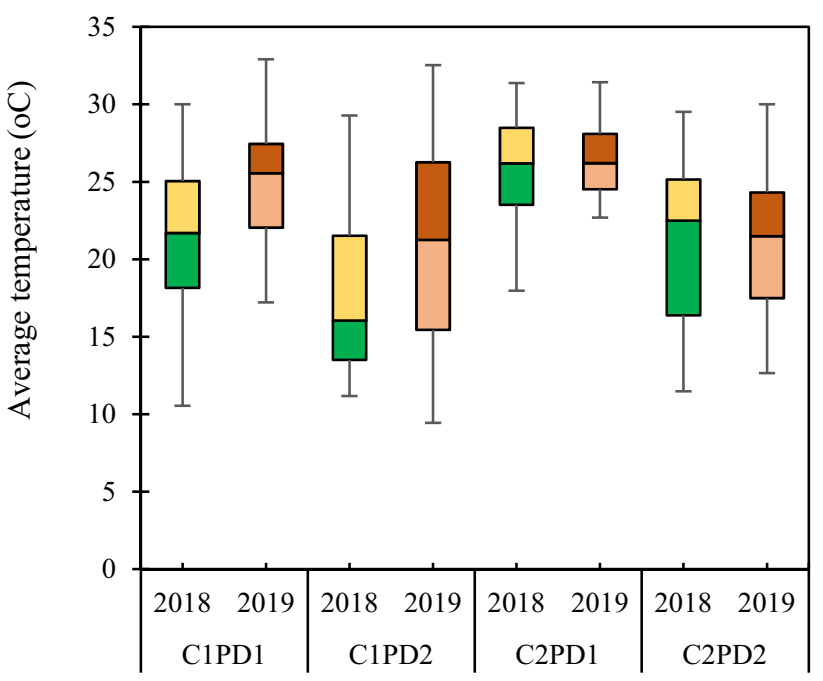

Treatments

Fig. 3 Variability of average daily temperatures $\left({ }^{\circ} \mathrm{C}\right)$ during the maize reproductive period (VT to R6) for different cultivars and planting dates in 2018 and 2019. The upper and lower hinges of the box indicate the 75 th percentile and 25 th percentile of the data set, respectively. The line in the box indicates the median value of the data, and the upper and lower whiskers represents the maximum and minimum of the data, respectively. The reproductive period of cultivars for each planting dates and years is indicated in Table 1. PD1, planting date June 21; PD2, planting date July 22; C1, cultivar KSC704; C2, cultivar KSC260

and also differences between the 2 years. The second year was warmer year during the reproductive period.

An irrigation regime with 6-day intervals and $\mathrm{N}$ rate of $184 \mathrm{~kg} \mathrm{ha}^{-1}$ were specified as typical non-stressed growing conditions. Furrow irrigation was used for irrigation. The closed-end furrows were constructed with a ditcher. The ridge and furrow widths were $40 \mathrm{~cm}$ and $20 \mathrm{~cm}$ respectively, and the depth of the furrow was $15 \mathrm{~cm}$. Based on the flow rate per furrow $(\sim 1.3 \mathrm{~L} / \mathrm{s}$.), water was delivered until the furrows were completely full and the duration of each irrigation event was recorded. The known flow rate of the irrigation pump was then used to estimate irrigation volumes. In total, the KSC704 cultivar received about $9200 \mathrm{~m}^{3} \mathrm{ha}^{-1}$ of water with 6-day irrigation timing and about $5800 \mathrm{~m}^{3} \mathrm{ha}^{-1}$ with 12-day irrigation timing. KSC260 received less water due to a shorter growing period and less irrigation events: $7800 \mathrm{~m}^{3} \mathrm{ha}^{-1}$ with 6-day irrigation timing and $4800 \mathrm{~m}^{3} \mathrm{ha}^{-1}$ with 12-day irrigation timing. The Food and Agriculture Organization (FAO) estimates the water requirement of latematuring maize cultivars in arid and semi-arid regions to be around 7000 to $8000 \mathrm{~m}^{3} \mathrm{ha}^{-1}$ (Faostat, 2017). Urea was used as the $\mathrm{N}$ source, as the common source of $\mathrm{N}$ fertilizer used by farmers and top-dressed in equal proportions at two stages: pre-planting and V4-V6 (4-6 leaves with visible collars) stage of maize growth. Fresh irrigation water was used from the main ditch for each replication, and excess water was not re-used.

\section{Sampling and Measurements}

In both years of cultivation, a set of phenological and morpho-physiological variables were measured. Approximately every week, ten marked plants of each subplot were checked to determine important phenological stages including days to germination, tasseling, silking, physiological maturity, and grain filling period. Destructive sampling was conducted for six and eight stages, including VT (tasseling) and R1 (silking), in the first and second year, respectively. Each sampling time, 4 maize plants were randomly selected and harvested from each subplot. After measuring plant height and leaf area index (LAI), the organs were separated and dried in a laboratory oven at $60^{\circ} \mathrm{C}$ until a constant weight $(\sim 48 \mathrm{~h})$ and subsequently leaf and stem weight were measured. The trend of changes in the desired characteristics was measured using destructive sampling and their maximum values, which often occurred in the VT and R1 stage, were recorded. A leaf area 
meter (LI-COR LI-3100C model, USA) was used to measure LAI. At the R6 (physiological maturity) stage 15 plants in an area of $\sim 11 \mathrm{~m}^{2}$ (4-m row length $\times 0.7$-m row spacing $\times 4$ rows) were cut from each subplot to measure stover yield, grain yield and harvest index (HI). The organs were separated and the following were measured: weights of organs, ear length, barren length, ear and cob diameter, rows ear ${ }^{-1}$, grains row ${ }^{-1}$, grains ear ${ }^{-1}$, and hundred grain weight.

After appearance of buds on the stem that will form ears, a Minolta SPAD-502chlorophyll meter (Minolta Camera Co., Ltd, Japan) was used for estimation of greenness index of the main ear leaf at R1 and R4 (dough) stages. Greenness index measurements were made on undamaged ear leaves of each of the 10 marked plants in each sub plot at the same time close to solar noon. To assess and characterize the ability of the varieties to photosynthetically utilize radiation for biomass production under different growing conditions, radiation use efficiency (RUE) was calculated (Dingkuhn et al., 2015; Zhang et al., 2009). Similar to Dingkuhn et al., (2015), the photosynthetically active radiation (PARi) was calculated from the dynamics of LAI by fitting two or three regression models that had the best coefficient of determination $\left(\mathrm{R}^{2}\right)$ to interpolate daily LAI values from planting to maturity (supplementary 1, Fig. S1 and Table S1). The fraction of light intercepted was estimated using Lambert-Beer's law (Monsi \& Saeki, 1953), with PARi $=$ PAR $\left(1-\mathrm{e}^{-k \mathrm{LAI}}\right)$; where $k$ is the extinction coefficient. The extinction coefficient was set at 0.49 for KSC704 and 0.52 for KSC260, adopted from the study of Jahangirlou (2015). Daily global solar radiation was converted into PAR by multiplying by 0.48 (Dingkuhn et al., 2015); then PARi was cumulated from sowing to maturity and used to estimate RUE from the final above ground dry weight, separately for each plot.

\section{Statistical Analysis}

Principal component scores were derived using Minitab, v.19 (Minitab Inc., 2006) after standardizing the variables by using the correlation matrix. Results from the two cultivation years were analyzed separately, using mixed model procedures with PROC MIXED (SAS Institute, 2003). The mixedeffects model included fixed effects of irrigation, planting date, cultivar, $\mathrm{N}$, and their interactions, and the random effects of irrigation*planting date and irrigation*planting date*block interactions. Because of the experimental design, irrigation effects have to be interpreted with caution-possible meaningful effects of irrigation and its interactions can be either caused by differences between the planned irrigation treatments, or by differences in the two sections of the field where the irrigation treatments were applied. Tukey's statistic was used to test differences $(\mathrm{P} \leq 0.05)$ among means.

\section{Results}

\section{Correlations Between Yield and its Component Variables and Agronomic Treatments}

The PCA comprising the first two principal components accounted for $51.5 \%$ of the total variance. In the loading plot (Fig. 4A) are the eigenvectors of characteristics for 31 variables related to growth and development of maize during the growing season. The maximum height $(\mathrm{Hm})$, tassel length $(\mathrm{TaLm})$, stem weight $(\mathrm{SWm})$, leaf weight $(\mathrm{LWm})$, tassel weight (TWm), and husk weight (HWm), and also maximum leaf area index (LAIm) shown in the loading plot belong to tasseling or silking stages (VT/R1).

Three informal clusters of correlated variables were made according to their distribution (similar eigenvector values and low angle between eigenvectors) in principal components 1 and 2 . In the first cluster, GY is highly correlated to stover yield (SY), ear weight (EW), and RUE. The correlation of these variables is confirmed by the correlation analysis (supplementary 2, Table S2). For instance, the correlation between GY and RUE was 0.824 (Table S4). In the second cluster, number of grains row $^{-1}$ (GR) is highly correlated to $\mathrm{Hm}$ and leaf greenness index (LGI) at silking (LGIs). The correlation between GR and LGIs was 0.508 . The eigenvector for grains ear ${ }^{-1}(\mathrm{GE})$ points in the opposite direction; thus, the three clustered variables were negatively correlated to GE. For example, the correlation between GE and GR was - 0.652. In the third cluster, HI, and hundred-grain weight (HGW) were highly correlated to SWm, stem weight (SW), leaf weight (LW), ear diameter (ED), ear length (EL), and number of rows $e^{-1}(\mathrm{RE})$ at physiological maturity. As an example, the correlation between SWm and ED is 0.582 .

The score plot (Fig. 4B) plots 2 years, two planting dates, two cultivars, two irrigation regimes, and two $\mathrm{N}$ rates, giving a total of 32 points, averaged across replicates. There was a noticeable pattern of different levels of irrigation and the years; so means in Fig. 4B were marked by these two factors, to highlight the effects. The first component approximately separates the high irrigation rate from the low irrigation rate-markers for the low irrigation rate, are often located in the left of the score plot, whereas markers for the high irrigation rate are often in the right. The second component clearly separates the first year of the experiment from the second year-markers for the first year (2018), are distributed toward the top of the score plot, whereas markers for the second year (2019) are located toward the bottom. The data points presented in score plots coincide with the direction of changes in variables in the loading plots. The variables from the first cluster and second cluster are associated most strongly with 


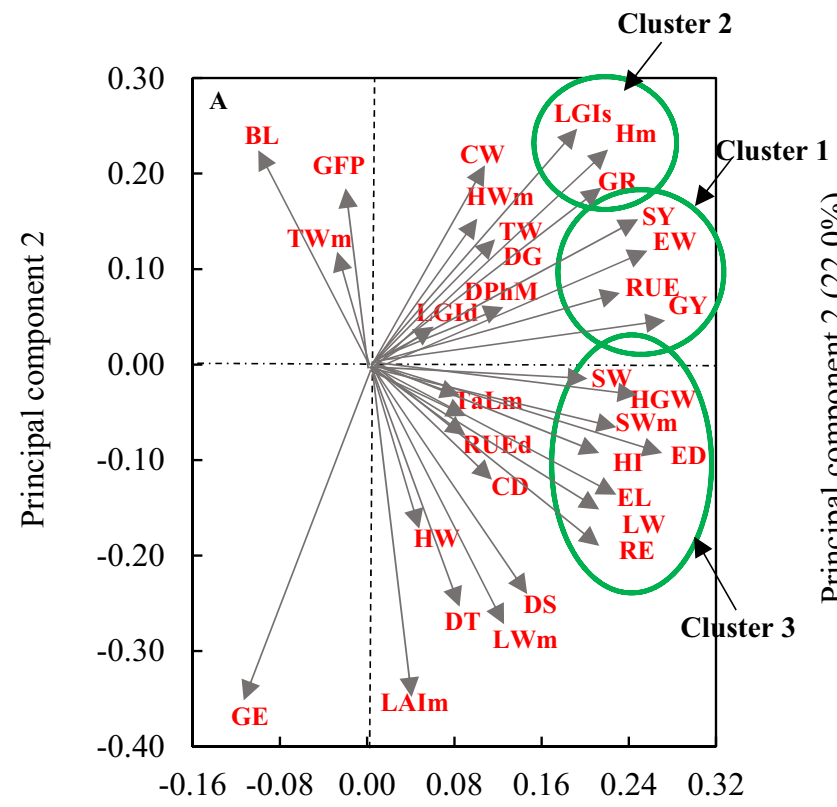

Principal component 1

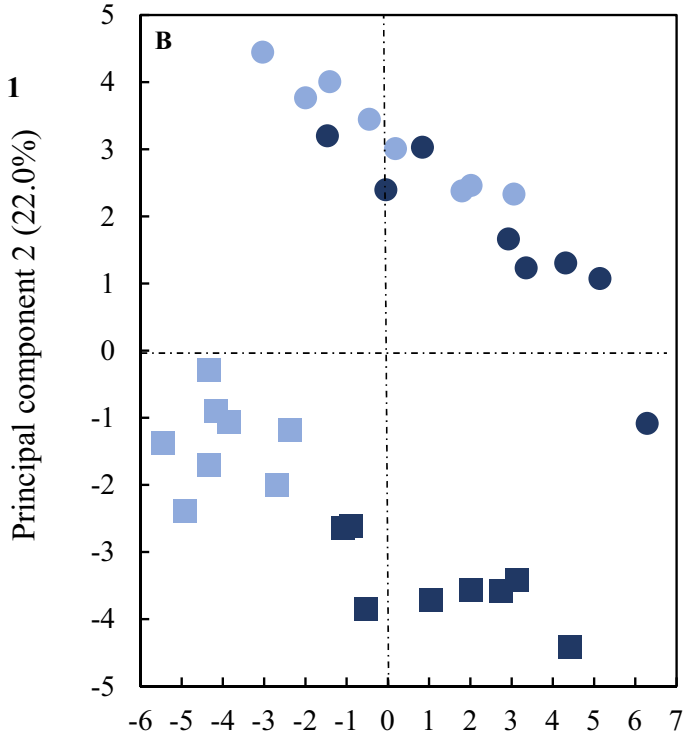

Principal component 1 (29.5\%)

2018-I1 —2019-I1 •2018-I2 —2019-I2
Fig. 4 Plots of principal component 1 versus principal component 2, based on measured maize crop characteristics. The loading plot $\mathbf{A}$ shows the eigenvector of each characteristic. The score plot $\mathbf{B}$ shows the means, grouped by year and irrigation treatments (I1, Irrigation at 12-day intervals; I2, Irrigation at 6 day-intervals). Each marker represents the mean of replicates in the field. Abbreviations for eigenvectors: $B L$ barren length, $C D$ cob diameter, $C W$ cob weight, $D G$ days to germination, $D P h M$ days to physiological maturity, $D S$ days to silking, $D T$ days to tasseling, $E D$ ear diameter, EW ear weight, $E L$ Ear length, $G E$ grains ear $^{-1}, G F P$ grain filling period, $G R$ grains row ${ }^{-1}$,

more frequent irrigation, and the year 2018. This means that plots with more frequent irrigation during 2018 are likely to have higher values for these measured variables. The variables from the third cluster are associated most strongly with more frequent irrigation, and the year 2019. The three clusters identified are all associated with more frequent irrigation. Also, LAI and GE are strongly associated with the 2019 season.

\section{Treatment Effects on Grain Yield and its Components}

The effects of treatment main effects on yield components are presented in Table 2 and significant interactions are plotted in Fig. 5 (unless no pairs of means were significantly different or the graph could not be clearly interpreted). P-values of all main effects and interactions for yield components are in supplementary material 3, Table S3. P-values and results of analysis of variance for vegetative characteristics are in supplementary material 4.
$G Y$ grain yield, $H W$ husk weight, $H W m$ maximum husk weight, $H G W$ hundred-grain weight, $H I$ harvest index, $H m$ maximum height, LAIm maximum leaf area index, LGId leaf greenness index at dough, LGIs leaf greenness index at silking, $L W$ Leaf weight, $L W m$ maximum leaf weight, $R E$ rows ear ${ }^{-1}, R U E$ radiation use efficiency, $S W$ stem weight, $S W m$ maximum stem weight, $S Y$ stover yield, TaLm maximum tassel length, $T W m$ maximum tassel weight, $T W$ tassel weight. The variables including BL, CD, CW, ED, EW, EL, GE, GR, GY, HW, HW, HI, LW, SW, SB and TW were measured at physiological maturity

In 2018, high $\mathrm{N}$ increased $\mathrm{GY}$ by one tonne ha ${ }^{-1}$ (Table 2). In addition, KSC260 had higher GY than KSC704 by 0.96 tonnes $\mathrm{ha}^{-1}$ (Table 2). In 2019, there were interaction effects of irrigation and $\mathrm{N}$ rate (Fig. 5A) and planting date and cultivar (Fig. 5B) on GY. Irrigation rate had the greatest effect, and for either irrigation rate, the high $\mathrm{N}$ rate increased GY (Fig. 5A). KSC704 with an early planting date had the highest GY (10.84 tonnes ha ${ }^{-1}$ ), whereas for KSC260 there was no planting date effect.

In 2018, EW with an early planting date was higher than with a late planting date by 4.57 tonnes ha ${ }^{-1}$ (Table 2). In 2018, KSC260 had a higher EW than KSC704 by 1.78 tonnes ha ${ }^{-1}$ (Table 2). In 2019, there were interaction effects of irrigation and $\mathrm{N}$ rate (Fig. 5C), irrigation and cultivar (Fig. 5D), and $\mathrm{N}$ rate and cultivar (Fig. 5E) on EW. For any irrigation rate, the high $\mathrm{N}$ rate increased $\mathrm{EW}$. In addition, EW was higher with the high irrigation rate, regardless of the $\mathrm{N}$ rate (Fig. 5C). For any cultivar, the high irrigation rate increased EW (Fig. 5D). For both cultivars, the high $\mathrm{N}$ rate increased EW (Fig. 5E). With high or low irrigation and $\mathrm{N}$ 
Table 2 Least squares means, significances and standard errors of maize grain yield, harvest index, ear weight, ear size (diameter and length), number of rows per ear, grains per row and hundred-grain weight, at physiological maturity, in response to treatment main effects (irrigation, planting date, cultivar and nitrogen rate) in 2018 and 2019

\begin{tabular}{|c|c|c|c|c|c|c|c|c|c|c|c|c|c|c|c|c|}
\hline \multirow[t]{2}{*}{ Treatment } & \multicolumn{2}{|c|}{$\begin{array}{l}\text { Grain yield } \\
\left(\text { tonnes } \mathrm{ha}^{-1} \text { ) }\right.\end{array}$} & \multicolumn{2}{|c|}{$\begin{array}{l}\text { Harvest index } \\
(\%)\end{array}$} & \multicolumn{2}{|c|}{$\begin{array}{l}\text { Ear weight } \\
\left(\text { tonnes } \mathrm{ha}^{-1} \text { ) }\right.\end{array}$} & \multicolumn{2}{|c|}{$\begin{array}{l}\text { Ear diameter } \\
(\mathrm{cm})\end{array}$} & \multicolumn{2}{|c|}{$\begin{array}{l}\text { Ear length } \\
(\mathrm{cm})\end{array}$} & \multicolumn{2}{|c|}{ Rows ear $^{-1}$} & \multicolumn{2}{|c|}{ Grains row $^{-1}$} & \multicolumn{2}{|c|}{$\begin{array}{l}\text { Hundred-grain } \\
\text { weight }(\mathrm{g})\end{array}$} \\
\hline & 201 & 2019 & 20 & 19 & 2018 & 20 & & 2019 & & 2019 & 2018 & 2019 & 8 & 2019 & 8 & 9 \\
\hline & & & & & & 8. & & & & & 14 & 14.29 & & 40.39 & & .80 \\
\hline & 3.19 & 7 & .77 & 3.20 & 7.21 & 13. & & 4. & & 20.25 & 15.49 & 6.38 & 48 & 42.93 & & 9.92 \\
\hline -val & 165 & 0.047 & 560 & 185 & 0.080 & 0.0 & 20 & 0.043 & 91 & 0.024 & 0.057 & 0.015 & 0.033 & 0.005 & 26 & 0.041 \\
\hline$E M$ & c & & & & 2 & 0 & & & & 06 & & .05 & 0 & .03 & & 0.42 \\
\hline 1 & 1 & & & 8.00 & 18.37 & 11 & & & & 19.69 & & 15.48 & & 41.66 & & 27.83 \\
\hline D2 & $\mathrm{c}$ & & & 44.35 & 13.80 & 10 & & 4. & & 19.13 & 14 & 15.18 & & 41.66 & & 27.65 \\
\hline -value & 0.099 & 0 & 0.097 & 0.203 & 0.039 & 0.749 & 10 & 0.252 & 0.321 & 0.072 & 0.435 & 0.108 & 0.106 & 0.909 & 0.112 & 0.738 \\
\hline$E M$ & 0.63 & & & 1 & 0.02 & 0. & 94 & 0. & & 0.06 & 0. & 0.05 & 0. & .03 & 0. & 0.42 \\
\hline C1 & & 9 & & 95 & 5.20 & 10 & & 4. & & 19.14 & 16.02 & 15.20 & 46 & 41.15 & 52 & 28.49 \\
\hline $\mathrm{C} 2$ & 12.46 & 8.82 & 48 & 46.40 & 16.98 & 10.94 & 4.30 & 4.2 & 18 & 19.68 & 14.62 & 15.46 & 44.32 & 42.17 & 24.93 & 26.99 \\
\hline$-v c$ & $<.001$ & .001 & .001 & 588 & 0.004 & 0.919 & $<.001$ & 0.017 & $<.001$ & 0.23 & 0. & 0.538 & $<.001$ & 0.143 & $<.001$ & 0.023 \\
\hline$E M$ & 0.24 & 0 & & & & & & & & 0.43 & 0 & 0.41 & 0. & 0.67 & 0. & 0 . \\
\hline NI & & & & 4. & 2 & 9. & & & & 15 & 14.43 & 15.35 & & 40.98 & 28.66 & $2 t$ \\
\hline $1 \sqrt{2}$ & 12.48 & 10.52 & 46.45 & 47.31 & 16.65 & 12.06 & 4.50 & 4. & 19.71 & 19.67 & 15.21 & 15.32 & 47.44 & 42.33 & 30.89 & 28.93 \\
\hline P-va & $<.001$ & $<.001$ & 0.711 & 0.010 & 0.061 & $<.001$ & $<.001$ & 0.035 & $<.001$ & 0.251 & $<.001$ & 0.940 & 0.002 & 0.044 & $<.001$ & $<.00$ \\
\hline SEM & 0.24 & 0.23 & 0.85 & 0.81 & 0.05 & 0.03 & 0.04 & 0.06 & 0.15 & 0.43 & 0.20 & 0.41 & 0.37 & 0.67 & 0.44 & 0.62 \\
\hline
\end{tabular}

$I 1$ irrigation at 12-day intervals, $I 2$ irrigation at 6 day-intervals, $P D 1$ planting date June 21, PD2 planting date July 22, $C 1$ cultivar KSC704, $C 2$ cultivar KSC260, N1 zero nitrogen, $N 2184 \mathrm{~kg} \mathrm{~N} \mathrm{ha}^{-1}$

rates, there was no significant difference between cultivars in terms of EW. In 2018, KSC260 had higher HI than KSC704 by $4.03 \%$ (Table 2). In 2019, high N increased HI by $2.27 \%$ (Table 2).

In 2018, ED with an early planting date was higher than with a late planting date by $0.26 \mathrm{~cm}$ (Table 2). In 2019, there were main effects of irrigation, cultivar and $\mathrm{N}$ rate on $\mathrm{ED}$ (Table 2). High irrigation and $\mathrm{N}$ rate increased ear diameter by 0.35 and $0.15 \mathrm{~cm}$, respectively. Cultivar KSC704 had higher ear diameter than KSC260 by $0.17 \mathrm{~cm}$ (Table 2). In 2018, there were interaction effects of irrigation and $\mathrm{N}$ rate (Fig. 5F) and cultivar and $\mathrm{N}$ rate (Fig. 5G) on ED. With the high irrigation rate, the high $\mathrm{N}$ rate increased $\mathrm{ED}(4.62 \mathrm{~cm})$, whereas with low irrigation there was no $\mathrm{N}$ effect. In $\mathrm{KSC} 704$, the high $\mathrm{N}$ rate increased ED $(4.65 \mathrm{~cm})$, whereas in KSC260 there was no $\mathrm{N}$ effect. In 2019, high irrigation increased EL by $1.68 \mathrm{~cm}$ (Table 2). In 2018, there was an interactive effect of cultivar and $\mathrm{N}$ rate (Fig. $5 \mathrm{H}$ ) on EL. In $\mathrm{KSC} 704$, the high $\mathrm{N}$ rate increased EL $(4.65 \mathrm{~cm})$, whereas in KSC260 there was no N effect. Cultivar KSC704 had higher EL than KSC260, regardless of the $\mathrm{N}$ rate.

In 2018, KSC704 had higher RE than KSC260 (Table 2). In addition in 2018, the high $\mathrm{N}$ rate and in 2019 the high irrigation rate increased RE (Table 2). In both years, high $\mathrm{N}$ and irrigation rate increased GR (Table 2). In 2018, there was an interactive effect of planting date and cultivar on GR (Fig. 5I). For KSC704, planting at early date increased
GR, whereas for KSC260 there was no planting date effect. For KSC704, GR was higher than for KSC260, regardless of the planting date. High N rate increased HGW by 2.23 and $2.39 \mathrm{~g}$ in 2018 and 2019, respectively. In 2019, high irrigation rate increased HGW by $4.06 \mathrm{~g}$. In 2019, KSC704 had higher HGW than KSC260 by $1.5 \mathrm{~g}$. In 2018 , there were interactive effects of cultivar and irrigation (Fig. 5J) and cultivar and planting date (Fig. 5K) on HGW. In KSC704, high irrigation increased HGW, whereas in KSC260 there was no irrigation effect. In both cultivars, HGW with an early planting date was higher than with a late planting date.

\section{Discussion}

\section{Physiological Basis of Correlations Between Yield and its Component Variables and AGRONOMIC Treatments}

The results showed that grain yield (GY) is highly correlated with stover yield, ear weight and radiation use efficiency (RUE). This is in line with the established theory that high biomass is associated with better genetic gains to produce high grain yield (Reynolds et al., 2017). However, in the areas faced with drought stress, increasing biomass (especially due to mass and area of leaves) does not always related to achieving higher grain yield, because there is strongly 


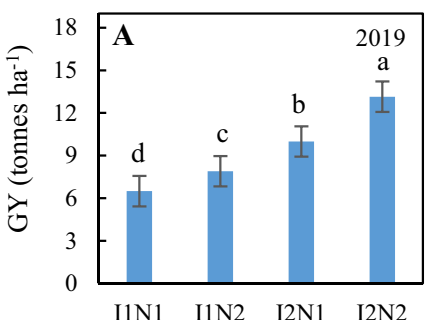

Treatments
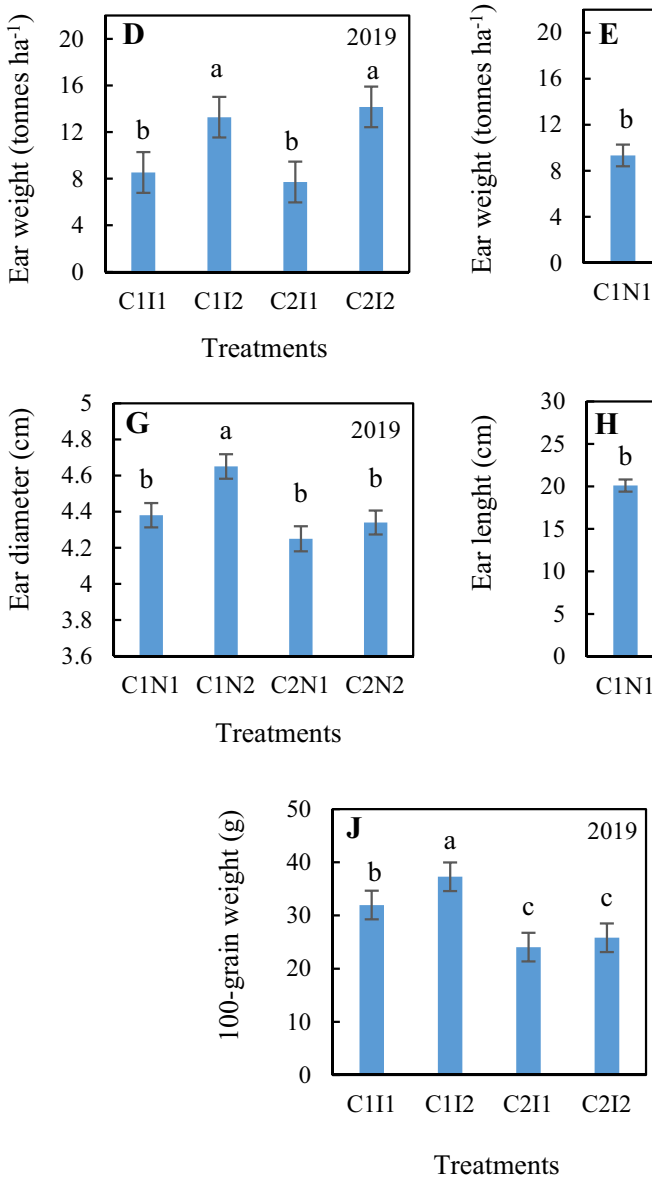

Fig. 5 Least squares means of maize grain yield (GY) in response to interaction effects of irrigation and nitrogen (A) and planting date and cultivar (B); ear weight in response to interaction effects of irrigation and nitrogen (C), cultivar and irrigation (D) and cultivar and nitrogen $(\mathbf{E})$; ear diameter in response to interaction effects of irrigation and nitrogen $(\mathbf{F})$ and cultivar and nitrogen $(\mathbf{G})$; ear length in response to interaction effects of cultivar and nitrogen $(\mathbf{H})$; number of grains row $^{-1}$ in response to interaction effects of cultivar and planting date

negative correlation between leaf water loss, transpiration and leaf size across the species (Wang et al., 2019). RUE is highly correlated with biomass production (Soufizadeh et al., 2018) and chlorophyll in the leaves, an indicator of $\mathrm{N}$ content which improves assimilate synthesis, biomass production, grain filling, and yield (Liu et al., 2018).

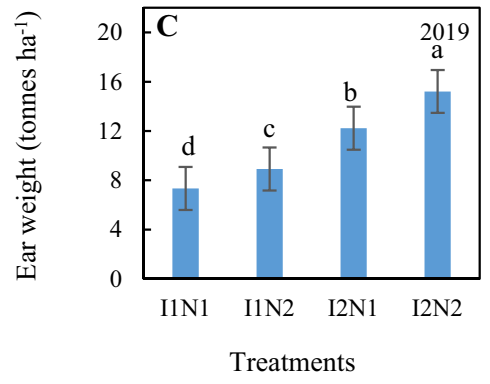

Treatments
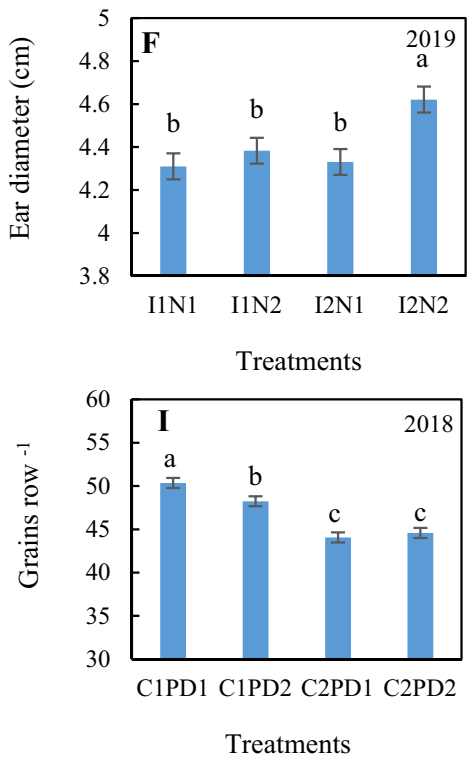

Treatments

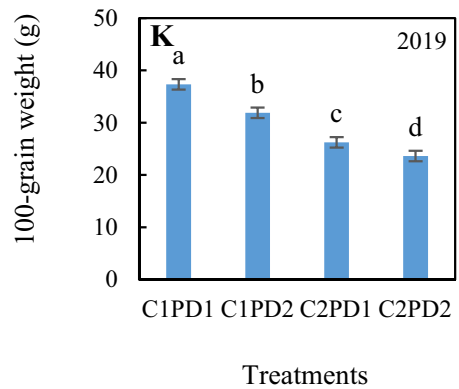

(I); 100-grain weight in response to interaction effects of cultivar and irrigation $(\mathbf{J})$, cultivar and planting date $(\mathbf{K})$. These graphs are only for significant interactions. $I 1$ irrigation at 12 -day intervals, $I 2$ irrigation at 6 day-intervals, $P D 1$ planting date June 21, $P D 2$ planting date July 22, $C 1$ cultivar KSC704, $C 2$ cultivar KSC260, N1 zero-nitrogen, $N 2184 \mathrm{~kg} \mathrm{~N} \mathrm{ha}^{-1}$. Least squares means labelled with the same letter do not differ significantly at $\mathrm{P}<0.05$, based on Tukey's test. Vertical bars represent the $95 \%$ confidence interval

The correlations between GY and RUE and grains row ${ }^{-1}$ (GR) and leaf greenness index (LGI) in the study indicate that results are in line with earlier studies. In the present study, LGI was measured in two stages (silking and dough), but LGI of ear leaves at silking had a higher correlation with grain yield and its components than LGI at dough stage. This 
is because tasseling and silking are extremely critical stages for pollination, kernel formation, and increasing the number of filled grains, and $\mathrm{N}$ and chlorophyll status of the plant at this stage has a significant effect on grain yield (Gaju et al., 2016). Additionally, the carbohydrate and $\mathrm{N}$ in the leaves at this stage are remobilized towards developing grains (Ning et al., 2018) in the grain development phase. As the crop moves closer to the maturity, the supply of carbohydrate and $\mathrm{N}$ for grain development becomes limiting, because the crop starts shedding the lower leaves and supplies the resources to the grain (Ning et al., 2018). Hence, the higher correlation of greenness index (an indicator of chlorophyll and nitrogen content) at tasseling than at dough stage is in accordance with the physiological mechanisms.

Similarly, the correlations between harvest index (HI), and grain yield components (hundred-grain weight (HGW), grains row $^{-1}$ (GR) and ear diameter and length) with vegetative characteristics (maximum stem weight at flowering, and stem and leaves weight at physiological maturity) further indicates the source-sink balancing phenomenon by the crop. In mature grains, the biggest part of dry matter is remobilized from pre-anthesis accumulated reservoirs of organs, especially from the stems (Crevelari et al., 2018). Stem weight at flowering is important for increasing grain weight and yield; in other words, stronger sink activity (e.g. HGW and GR, and larger ear size) is one of the main reasons for achieving greater grain weight (Zhao et al., 2020).

The results of this study suggest that irrigation and year accounted for much of the data variation. Sah et al. (2020) reported recently that water stress explained up to $66 \%$ of changes in grain yield characteristics in non-drought tolerant maize lines. Two main potential sources can be considered for the differences among years herein: (a) conducting the first cultivation after 3 years fallow, and (b) differences of daily temperature during the reproductive stage among years. Keeping soil fallow for a season or more improves soil fertility, organic matter and physical properties to supply more elements needed for assimilation; whereas, continuous cultivation as performed in this study could make some elements deficient for grain growth and development. Zhu et al. (2019) reported that high temperature can affect maize grain yield greatly. More than half of the yield changes of maize in the U.S. Midwest was related to temperature variations among years during the grain filling period.

\section{Coupling the Responses of Grain Yield and its Component with Agronomic Treatments}

The results of the first year showed that high $\mathrm{N}$ rate increased GY. This result was not surprising because the application of $\mathrm{N}$ fertilizer increases the $\mathrm{N}$ content in leaves, which is strongly correlated with high greenness index or chlorophyll content and increasing the activities of chloroplast, thereby increasing the photosynthetic rate and grain yield (Li et al., 2013). In the second year, for any irrigation rate, high $\mathrm{N}$ rate increased GY and EW, and they were higher in high irrigated treatments, regardless of the $\mathrm{N}$ rate. These results suggested that irrigation was more critical than $\mathrm{N}$, and they are in line with the results obtained by Di Paolo and Rinaldi, (2008), who reported $\mathrm{N}$ application amplified the irrigation effect and vice versa.

Surprisingly in the first year, early maturity cultivar KSC260 had higher GY and EW than the late maturity cultivar KSC704. However, in the second year with the continued cultivation, KSC704 in early planting date had higher grain than KSC260, whereas it declined in late planting. Late maturing cultivars are high yielding because of the longer vegetative and reproductive stage, but have higher requirements for solar radiation, water, and nutrition (Huang et al., 2020). Besides the genotype factor (G), the agronomic management factor $(\mathrm{M})$ of planting late maturity cultivars earlier in arid regions can take advantage of late spring rainfalls which facilitates its germination and establishment, and together with less chances to be exposed to the temperature drop in autumn at the end of the growing season, an environmental factor (E) (Wang et al., 2017), KSC704 might be exposed to conducive $\mathrm{G} \times \mathrm{E} \times \mathrm{M}$ in the second year, particularly for better grain development. Although higher grain yield was observed for KSC260 in the first year and also in late planting date of the second year compared to KSC704, there was no significant difference between GY of KSC704 and KSC260. Considering the results of the second year, it can be stated that KSC260 can provide more flexibility to crop managers to shift planting times and allows producers in certain production areas to harvest before the onset of inclement weather.

In addition, the reasons for higher grain yield of KSC260 in the first year can be linked with the individual genotypic traits. In KSC260, there was a high frequency of doubleear plants, whereas KSC704 plants were mostly single-ear. KSC260 had all the grains filled in the secondary ears, which was unusual as secondary ears are usually barren in maize or only can produce 5 to $10 \%$ of primary ear grains (Nafziger, 1996). However, some studies reported that the growth and development of secondary ears can be affected by environmental stress factors like temperature (Li, 2013). This could be the potential reason for the increased frequency of barren secondary ears of KSC260 and reduced its GY, in 2019. In general, the inconsistency in GY among years and planting dates could suggest a large impact of exogenous factors like edaphic and climatic variables, in addition to the maturity group and genetic potentials on grain yield (Maresma et al., 2019), which can further be associated with the complexities of $\mathrm{G} \times \mathrm{E} \times \mathrm{M}$.

In the first year, EW was higher in the early planting date than the late one. However, it seems that the increase 
in EW was due to the increase in the straw part, rather than the grain, because there was no significant difference between planting dates in terms of grain yield. In the second year, for any cultivars, the high irrigation and $\mathrm{N}$ rate increased EW, similar to Ercoli et al. (2009) who reported that higher irrigation and $\mathrm{N}$ regimes can increase organ biomass (e.g. ears) by increasing the rate of assimilate production.

The HI was higher in KSC260 than KSC704 in the first year, which can be associated with the higher GY and EW. However, the other yield components i.e. RE, GR, and $\mathrm{HGW}$, which contribute to the yield and thus influence $\mathrm{HI}$ were lower than KSC704. This again suggests that the secondary ears of KSC260 and its filled grains were important factors for grain yield and HI differences among the cultivars. Considering the early maturing characteristics of KSC260 and its potential to escape from the high temperature stress during reproductive stages the responses of the cultivar are in accordance with the study of Kobata et al. (2018). In the second year, HI of KSC260 was higher than KSC704 but there was no significant difference between cultivars, which similar to the first year, can be attributed to EW of the cultivars. In addition, the HI increase with high $\mathrm{N}$ in the second year can be explained by the fact that $\mathrm{N}$ application enhances the physiological efficiency in the translocation of photosynthetic products to kernel number and weight which increases grain yield and subsequently HI (Asibi et al., 2019). In response to different irrigation and planting date treatments, HI during 2 years of cultivation was variable but not significantly different, which suggested that it was stable under those conditions. A similar response where HI was variable in different years and managements but was statistically stable, reported by Kumar et al. (2016).

The increased ED and EL in response to the main or interactive effect of high irrigation and $\mathrm{N}$ rate might explain water and nutrition utilization ability of the crop. Ear diameter as an important criterion to reflect crop status in terms of the interplant competition is expected to increase in response to high utilization of water and nutrition in the plant canopy, as a consequence of increasing accumulation of plant biomass, its translocation to ear biomass, and the efficiency of using this biomass for kernel set (Borrás \& VitantonioMazzini, 2018). However, the response of ED to $\mathrm{N}$ rates varied with maize cultivars. One possible reason for this discrepancy can be related to genotypic characteristics. It is reported that cultivar KSC704 potentially has a bigger ear size than earlier maturing cultivars (Rafiee \& Kalhor, 2016).

For any year of cultivation, high irrigation and $\mathrm{N}$ rate increased GR and high $\mathrm{N}$ rate increased HGW. The high $\mathrm{N}$ rate increased $\mathrm{RE}$ in the first year, and high irrigation rate increased RE and HGW in the second year. These observations are expected because of high $\mathrm{N}$ and irrigation effects on forming and filling more ovules (potential grains) of maize ear and their effects on increasing grain cellular proliferation and growth (Echarte \& Tollenaar, 2006).

In the first year, the response of GR to planting dates was variable between cultivars. In the second year, the response of HGW to irrigation and planting date was variable between cultivars. In general, KSC704 had the highest GR and HGW. Jahangirlou (2015) reported higher GY and yield components of KSC704 compared to other local cultivars. Plant maturity is usually an important factor in the development of yield in maize.

Prolonged maturity makes more days available for higher biomass and grain yield production, if the environmental conditions at the end of the growth season are favorable (Jahangirlou, 2015). The results of second year showed that HGW decreased with late planting, regardless of cultivar, which could be associated with low temperatures and high diurnal temperature range which decrease kernel growth rate and ultimately final kernel weight (Zhou et al., 2017).

The results from the analysis of variance were generally in line with the results of principal component analysis, however, some non-commonalities are expected, because the score plot only shows means grouped by irrigation and year of principle components 1 versus 2 , whereas correlation matrix values take into account all dimensions (Parsons et al., 2006).

\section{Conclusion}

The findings provide insights into the phenotypic variables that are strongly correlated with grain yield and its components in accordance with the physiological mechanisms. Stover yield, RUE, height, LGI, stem weight at flowering, and ear size were strongly correlated with GY, yield components and HI. Irrigation and year had the greatest effect on maize crop characteristics. More irrigation (6-day intervals) or $\mathrm{N}$ rate $\left(184 \mathrm{~kg} \mathrm{~N} \mathrm{ha}^{-1}\right)$, or their interaction significantly increased GY and yield components. KSC260 had a higher GY in the first year across the treatments and KSC704 had a higher GY only in the early planting date of the second year. The inconsistency of cultivars GY among years and planting dates can further be associated with the complexities of $\mathrm{G}$ $\times \mathrm{E} \times \mathrm{M}$. However, KSC260, the early maturity cultivar, is more recommended because of good performance, greater flexibility to be used at various planting times, a 15-20 days earlier maturing cycle, and $1000 \mathrm{~m}^{3} \mathrm{ha}^{-1}$ less water consumption than KSC704. The findings are useful for understanding the importance of nitrogen, and selecting cultivars and planning irrigation in semi-arid conditions, where the dry and short growing season are important challenges in dent maize cultivation. In addition, the reported responses of genotypic traits under varied management practices can 
help crop improvement researchers develop high yielding maize cultivars in the future.

Supplementary Information The online version contains supplementary material available at https://doi.org/10.1007/s42106-021-00151-7.

Acknowledgements We wish to thank Mohammad Mahdi Mesbah Zadeh for help in collecting experimental data. The authors would like to thank Agricultural Research, Education \& Extension Organization of Iran (AREEO) for their financial contributions. The authors also would like to thank Dr. Mårten Hetta for his valuable guidance with the selecting morpho-physiological variables for analysis.

Funding Open access funding provided by Swedish University of Agricultural Sciences.

\section{Declarations}

Conflict of Interest The authors declare no competing interests.

Open Access This article is licensed under a Creative Commons Attribution 4.0 International License, which permits use, sharing, adaptation, distribution and reproduction in any medium or format, as long as you give appropriate credit to the original author(s) and the source, provide a link to the Creative Commons licence, and indicate if changes were made. The images or other third party material in this article are included in the article's Creative Commons licence, unless indicated otherwise in a credit line to the material. If material is not included in the article's Creative Commons licence and your intended use is not permitted by statutory regulation or exceeds the permitted use, you will need to obtain permission directly from the copyright holder. To view a copy of this licence, visit http://creativecommons.org/licenses/by/4.0/.

\section{References}

Adnan, A. A., Diels, J., Jibrin, J. M., Kamara, A. Y., Shaibu, A. S., Craufurd, P., \& Menkir, A. (2020). CERES-Maize model for simulating genotype-by-environment interaction of maize and its stability in the dry and wet savannas of Nigeria. Field Crops Research, 253, 107826. https://doi.org/10.1016/j.fcr.2020.107826

Asibi, A. E., Chai, Q., \& Coulter, A. J. (2019). Mechanisms of nitrogen use in maize. Agronomy, 9(12), 775. https://doi.org/10.3390/agron omy 9120775

Boomsma, C. R., Santini, J. B., West, T. D., Brewer, J. C., McIntyre, L. M., \& Vyn, T. J. (2010). Maize grain yield responses to plant height variability resulting from crop rotation and tillage system in a long-term experiment. Soil and Tillage Research, 106(2), 227-240. https://doi.org/10.1016/j.still.2009.12.006

Borrás, L., \& Vitantonio-Mazzini, L. N. (2018). Maize reproductive development and kernel set under limited plant growth environments. Journal of Experimental Botany, 69(13), 3235-3243. https://doi.org/10.1093/jxb/erx452

Bremner, J. M. (1960). Determination of nitrogen in soil by the Kjeldahl method. The Journal of Agricultural Science, 55(1), 11-33. https://doi.org/10.1017/S0021859600021572

Chen, C., Fletcher, A. L., Ota, N., Flohr, B. M., Lilley, J. M., \& Lawes, R. A. (2020). Spatial patterns of estimated optimal flowering period of wheat across the southwest of Western Australia. Field Crops Research, 247, 107710. https://doi.org/10.1016/j.fcr.2019. 107710
Crevelari, J. A., Durães, N. N. L., Bendia, L. C. R., Vettorazzi, J. C. F., Entringer, G. C., Ferreira Júnior, J. A., \& Pereira, M. G. (2018). Correlations between agronomic traits and path analysis for silage production in maize hybrids. Bragantia, 77(2), 243-252. https:// doi.org/10.1590/1678-4499.2016512

Cutforth, H. W., \& Shaykewich, C. F. (1990). A temperature response function for corn development. Agricultural and Forest Meteorology, 50(3), 159-171. https://doi.org/10.1016/0168-1923(90) 90051-7

Di Paolo, E., \& Rinaldi, M. (2008). Yield response of corn to irrigation and nitrogen fertilization in a Mediterranean environment. Field Crops Research, 105(3), 202-210. https://doi.org/10.1016/j.fcr. 2007.10.004

Dingkuhn, M., Laza, M. R. C., Kumar, U., Mendez, K. S., Collard, B., Jagadish, K., \& Rebolledo, M. C. (2015). Improving yield potential of tropical rice: achieved levels and perspectives through improved ideotypes. Field Crops Research, 182, 43-59. https:// doi.org/10.1016/j.fcr.2015.05.025

Echarte, L., \& Tollenaar, M. (2006). Kernel set in maize hybrids and their inbred lines exposed to stress. Crop Science, 46(2), 870-878. https://doi.org/10.2135/cropsci2005.0204

Emadodin, I., Reinsch, T., \& Taube, F. (2019). Drought and desertification in Iran. Hydrology, 6(3), 66. https://doi.org/10.3390/hydro $\log 6030066$

Ercoli, L., Masoni, A., Mariotti, M., \& Arduini, I. (2009). Accumulation of dry matter and nitrogen in durum wheat during grain filling as affected by temperature and nitrogen rate. Italian Journal of Agronomy. https://doi.org/10.4081/ija.2009.1.3

Estakhr, A., Heidari, B., \& Ahmadi, Z. (2015). Evaluation of kernel yield and agronomic traits of European maize hybrids in the temperate region of Iran. Archives of Agronomy and Soil Science, 61(4), 475-491. https://doi.org/10.1080/03650340.2014.941822

FAOSTAT. (2017). Statistical databases and data-sets of the Food and Agriculture Organization of the United Nations. http://www.fao. org

Gaju, O., DeSilva, J., Carvalho, P., Hawkesford, M. J., Griffiths, S., Greenland, A., \& Foulkes, M. J. (2016). Leaf photosynthesis and associations with grain yield, biomass and nitrogen-use efficiency in landraces, synthetic-derived lines and cultivars in wheat. Field Crops Research, 193, 1-15. https://doi.org/10.1016/j.fcr.2016.04. 018

Huang, M., Wang, J., Wang, B., Li, L. D., Yu, Q., He, D., \& Pan, X. (2020). Optimizing sowing window and cultivar choice can boost China's maize yield under $1.5^{\circ} \mathrm{C}$ and $2{ }^{\circ} \mathrm{C}$ global warming. Environmental Research Letters, 15(2), 024015.

Institute, S. A. S. (2003). The SAS system. V.9.4. Cary: SAS Institute.

Jahangirlou, R. M. (2015). Investigation of the morphophysiological aspects of yield formation in maize (Zea mays L.) cultivars and the agro-ecological assessment of their performance in Khouzestan and Fars provinces. MSc thesis, Shahid Beheshti University, Iran

Kobata, T., Koç, M., Barutçular, C., Tanno, K. I., \& Inagaki, M. (2018). Harvest index is a critical factor influencing the grain yield of diverse wheat species under rain-fed conditions in the Mediterranean zone of southeastern Turkey and northern Syria. Plant Production Science, 21(2), 71-82. https://doi.org/10.1080/13439 43X.2018.1445534

Kumar, U., Laza, M. R., Soulié, J. C., Pasco, R., Mendez, K. V., \& Dingkuhn, M. (2016). Compensatory phenotypic plasticity in irrigated rice: sequential formation of yield components and simulation with SAMARA model. Field Crops Research, 193, 164-177. https://doi.org/10.1016/j.fcr.2016.04.036

Kumar, U., Laza, M. R., Soulié, J. C., Pasco, R., Mendez, K. V., \& Dingkuhn, M. (2017). Analysis and simulation of phenotypic plasticity for traits contributing to yield potential in twelve rice 
genotypes. Field Crops Research, 202, 94-107. https://doi.org/10. 1016/j.fcr.2016.04.037

Li, D., Tian, M., Cai, J., Jiang, D., Cao, W., \& Dai, T. (2013). Effects of low nitrogen supply on relationships between photosynthesis and nitrogen status at different leaf position in wheat seedlings. Plant Growth Regulation, 70(3), 257-263. https://doi.org/10. 1007/s10725-013-9797-4

Li, L. (2013). Barrenness and Plant-to-Plant Variability in Maize (Zea mays L.), Doctoral dissertation, University of Guelf. Canada

Liu, Z., Gao, J., Gao, F., Liu, P., Zhao, B., \& Zhang, J. (2018). Photosynthetic characteristics and chloroplast ultrastructure of summer maize response to different nitrogen supplies. Frontiers in Plant Science, 9, 576. https://doi.org/10.3389/fpls.2018.00576

Maresma, A., Ballesta, A., Santiveri, F., \& Lloveras, J. (2019). Sowing date affects maize development and yield in irrigated Mediterranean environments. Agriculture, 9(3), 67. https://doi.org/10.3390/ agriculture 9030067

Mehlich, A. (1953). Determination of $\mathrm{P}, \mathrm{Ca}, \mathrm{Mg}, \mathrm{K}, \mathrm{Na}$, and NH4. North Carolina Soil Test Division (Mimeo 1953), pp. 23-89.

Minitab. (2006). L.L.C. SAS, v.19. State College: Minitab. Inc.

Modarres, R., \& da Silva, V. D. P. R. (2007). Rainfall trends in arid and semi-arid regions of Iran. Journal of Arid Environments, 70(2), 344-355. https://doi.org/10.1016/j.jaridenv.2006.12.024

Monsi, M., \& Saeki, T. (1953). U” ber den Lichtfaktor in den Pflanzengesellschaften und seine Bedeutung $\mathrm{f}^{\prime} \mathrm{u}{ }^{\prime} \mathrm{r}$ die Stoffproduktion. Journal of Japanese Botany, 14, 22-52.

Moradi, R., Koocheki, A., \& Mahallati, M. N. (2014). Adaptation of maize to climate change impacts in Iran. Mitigation and Adaptation Strategies for Global Change, 19(8), 1223-1238. https://doi. org/10.1007/s11027-013-9470-2

Moradi, R., Koocheki, A., Mahallati, M. N., \& Mansoori, H. (2013). Adaptation strategies for maize cultivation under climate change in Iran: irrigation and planting date management. Mitigation and Adaptation Strategies for Global Change, 18(2), 265-284. https:// doi.org/10.1007/s11027-012-9410-6

Murungweni, C., Van Wijk, M. T., Smaling, E. M. A., \& Giller, K. E. (2016). Climate-smart crop production in semi-arid areas through increased knowledge of varieties, environment and management factors. Nutrient Cycling in Agroecosystems, 105(3), 183-197. https://doi.org/10.1007/s10705-015-9695-4

Nafziger, E. D. (1996). Effects of missing and two-plant hills on corn grain yield. Journal of Production Agriculture, 9(2), 238-240. https://doi.org/10.2134/jpa1996.0238

Nasielski, J., \& Deen, B. (2019). Nitrogen applications made close to silking: implications for yield formation in maize. Field Crops Research, 243, 107621. https://doi.org/10.1016/j.fcr.2019.107621

Ning, P., Peng, Y., \& Fritschi, F. B. (2018). Carbohydrate dynamics in maize leaves and developing ears in response to nitrogen application. Agronomy, 8(12), 302. https://doi.org/10.3390/agronomy81 20302

Olsen, S. R. (1954). Estimation of available phosphorus in soils by extraction with sodium bicarbonate (No. 939). US Department of Agriculture.

Padovan, G., Martre, P., Semenov, M. A., Masoni, A., Bregaglio, S., Ventrella, D., Lorite, I., Santos, C., Bindi, M., Ferrise, R., \& Dibari, C. (2020). Understanding effects of genotypex environment $\times$ sowing window interactions for durum wheat in the Mediterranean basin. Field Crops Research, 259, 107969. https:// doi.org/10.1016/j.fcr.2020.107969

Parsons, D., Cherney, J. H., \& Gauch, H. G., Jr. (2006). Alfalfa fiber estimation in mixed stands and its relationship to plant morphology. Crop Science, 46(6), 2446-2452. https://doi.org/10.2135/ cropsci2006.03.0144

Reynolds, M. P., Pask, A. J., Hoppitt, W. J., Sonder, K., Sukumaran, S., Molero, G., \& Gonzalez, F. G. (2017). Strategic crossing of biomass and harvest index-source and sink-achieves genetic gains in wheat. Euphytica, 213(11), 257. https://doi.org/10.1007/ s10681-017-2040-z

Ruiz, M. B., D’Andrea, K. E., \& Otegui, M. E. (2019). Phenotypic plasticity of maize grain yield and related secondary traits: differences between inbreds and hybrids in response to contrasting water and nitrogen regimes. Field Crops Research, 239, 19-29. https://doi.org/10.1016/j.fcr.2019.04.004

Sah, R. P., Chakraborty, M., Prasad, K., Pandit, M., Tudu, V. K., Chakravarty, M. K., Narayan, M., Rana, N., \& Moharana, D. (2020). Impact of water deficit stress in maize: phenology and yield components. Scientific Reports, 10(1), 1-15. https://doi.org/ 10.1038/s41598-020-59689-7

Sarlikioti, V., De Visser, P. H. B., \& Marcelis, L. F. M. (2011). Exploring the spatial distribution of light interception and photosynthesis of canopies by means of a functional-structural plant model. Annals of Botany, 107(5), 875-883. https://doi.org/10.1093/aob/ mcr006

Shi, P., Tang, L., Lin, C., Liu, L., Wang, H., Cao, W., \& Zhu, Y. (2015). Modeling the effects of post-anthesis heat stress on rice phenology. Field Crops Research, 177, 26-36. https://doi.org/10.1016/j. fcr.2015.02.023

Soufizadeh, S. (2012). GDD calculator program. Iran: Shahid Beheshti University.

Soufizadeh, S., Munaro, E., McLean, G., Massignam, A., van Oosterom, E. J., Chapman, S. C., Messina, C., Cooper, M., \& Hammer, G. L. (2018). Modelling the nitrogen dynamics of maize crops-enhancing the APSIM maize model. European Journal of Agronomy, 100, 118-131. https://doi.org/10.1016/j.eja.2017.12. 007

Studnicki, M., Wijata, M., Sobczyński, G., Samborski, S., Gozdowski, D., \& Rozbicki, J. (2016). Effect of genotype, environment and crop management on yield and quality traits in spring wheat. Journal of Cereal Science, 72, 30-37. https://doi.org/10.1016/j.jcs. 2016.09.012

Tsimba, R., Edmeades, G. O., Millner, J. P., \& Kemp, P. D. (2013). The effect of planting date on maize: Phenology, thermal time durations and growth rates in a cool temperate climate. Field Crops Research, 150, 145-155. https://doi.org/10.1016/j.fcr.2013.05.021

Villegas, D., Alfaro, C., Ammar, K., Cátedra, M. M., Crossa, J., García del Moral, L. F., \& Royo, C. (2016). Daylength, temperature and solar radiation effects on the phenology and yield formation of spring durum wheat. Journal of Agronomy and Crop Science, 202(3), 203-216. https://doi.org/10.1111/jac.12146

Walkley, A., \& Black, I. A. (1934). An examination of the Degtjareff method for determining soil organic matter, and a proposed modification of the chromic acid titration method. Soil Science, 37(1), 29-38.

Wang, C., He, J., Zhao, T. H., Cao, Y., Wang, G., Sun, B., \& Li, M. H. (2019). The smaller the leaf is, the faster the leaf water loses in a temperate forest. Frontiers in Plant Science, 10, 58. https://doi. org/10.3389/fpls.2019.00058

Wang, X., \& Xing, Y. (2017). Effects of irrigation and nitrogen on maize growth and yield components. Global changes and natural disaster management: geo-information technologies (pp. 63-74). Cham: Springer. https://doi.org/10.1007/978-3-319-51844-2_5

Zhang, Y., Tang, Q., Zou, Y., Li, D., Qin, J., Yang, S., Chen, L., Xia, B., \& Peng, S. (2009). Yield potential and radiation use efficiency of "super" hybrid rice grown under subtropical conditions. Field Crops Research, 114(1), 91-98. https://doi.org/10.1016/j.fcr.2009. 07.008

Zhao, B., Ma, B. L., Hu, Y., \& Liu, J. (2020). Source-sink adjustment: a mechanistic understanding of the timing and severity of drought stress on photosynthesis and grain yields of two contrasting oat (Avena sativa L.) genotypes. Journal of Plant Growth Regulation. https://doi.org/10.1007/s00344-020-10093-5 
Zhou, B., Serret, M. D., Pie, J. B., Shah, S. S., \& Li, Z. (2018). Relative contribution of nitrogen absorption, remobilization, and partitioning to the ear during grain filling in chinese winter wheat. Frontiers in Plant Science, 9, 1351. https://doi.org/10.3389/fpls. 2018.01351

Zhou, X., Xu, Y., \& Zhang, F. (2017). Evaluation of effect of diurnal ambient temperature range on solar chimney power plant performance. International Journal of Heat and Mass Transfer, 115, 398-405. https://doi.org/10.1016/j.ijheatmasstransfer.2017. 07.051

Zhu, P., Zhuang, Q., Archontoulis, S. V., Bernacchi, C., \& Müller, C. (2019). Dissecting the nonlinear response of maize yield to high temperature stress with model-data integration. Global Change Biology, 25(7), 2470-2484. https://doi.org/10.1111/gcb.14632 